\title{
Pearls \& Oy-sters: Rosai-Dorfman Disease of the CNS
}

Kia Gilani*, MD, Stephanie Kuntz*, MD, David G. Munoz, MD, FRCP(C), and

Raphael Schneider, MD, PhD, FRCP(C)

Neurology ${ }^{\circledR}$ 2021;96:1055-1058. doi:10.1212/WNL.0000000000012035
Correspondence

Dr. Schneider

raphael.schneider@

unityhealth.to

\section{Pearls}

- Rosai-Dorfman disease (RDD) is a rare histiocytosis that typically presents with painless lymphadenopathy but can also present with neurologic symptoms.

- Sometimes described as a non-neoplastic lymphoproliferative disease, RDD often has a favorable prognosis.

- Histology can be pathognomonic for RDD when lymphocytes are found embedded in the cytoplasm of macrophages, a phenomenon termed emperipolesis.

\section{Oy-sters}

- $\mathrm{RDD}$ of the nervous system can be challenging to diagnose as it often presents with isolated and nonspecific neurologic symptoms.

- $\mathrm{RDD}$ affecting the nervous system can be mistaken for meningioma, as both typically present as a uniformly enhancing extra-axial mass. RDD should be considered in the differential diagnosis for a mass resembling meningioma on imaging.

- RDD can co-occur with autoimmune diseases including systemic lupus erythematous, arthritis, or autoimmune hemolytic anemia; its relationship to immunoglobulin $\mathrm{G}$ ( $\operatorname{IgG}$ ) 4-related disease remains to be clarified.

A 61-year-old woman with a medical history of Bell palsy, carpal tunnel syndrome, and remote hepatitis B infection presented to the hospital with right eye visual blurring. Six weeks before this presentation, she had a new severe headache in the right periorbital and temporal areas. She had also experienced burning pain in the distribution of the trigeminal nerve and dysesthesia in the right forehead when brushing her hair. The headache and dysesthesia had spontaneously resolved the week before presentation to the hospital.

The patient's visual examination was normal despite subjective mild right eye blurriness. On further cranial nerve examination, she did not endorse dysesthesia, allodynia, or decreased sensation in the trigeminal nerve distribution. The remainder of the cranial nerve examination, the motor examination including deep tendon reflexes, and the sensory, coordination, and gait examination were all unremarkable. The patient's visual changes self-resolved after 2 days without treatment.

A CT scan of the head identified a hypodense right temporal lobe mass, initially suspected to be a primary CNS neoplasm (figure 1, A-C). An MRI of the brain demonstrated a T2 hyperintense mass in the temporal lobe (figure 1D), with adjacent thickening and enhancing of soft tissue and pachymeningeal enhancement (figure 1E). In addition, there was suspected leptomeningeal enhancement over the bilateral frontoparietal lobes, remote from the primary mass. The infiltrative process also involved the right cavernous sinus, encased the carotid artery, and there was perineural spread into the right foramen ovale. There was no MRI evidence of visual system or ophthalmic division of the trigeminal nerve involvement to explain the patient's subjective right

\footnotetext{
*These authors contributed equally to this work.
}

From the Department of Medicine, Division of Neurology (K.G., S.K., R.S.), and Department of Laboratory Medicine \& Pathobiology (D.G.M.), University of Toronto; Unity Health Toronto (D.G.M., R.S.); and St. Michael's Hospital (D.G.M., R.S.), Toronto, Canada.

Go to Neurology.org/N for full disclosures. Funding information and disclosures deemed relevant by the authors, if any, are provided at the end of the article. 


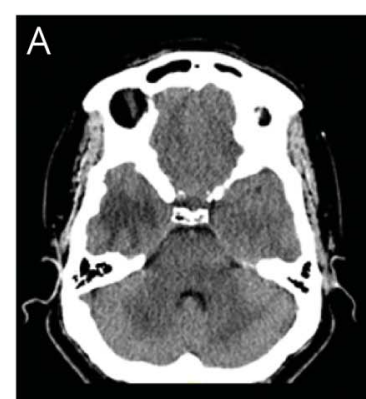

D
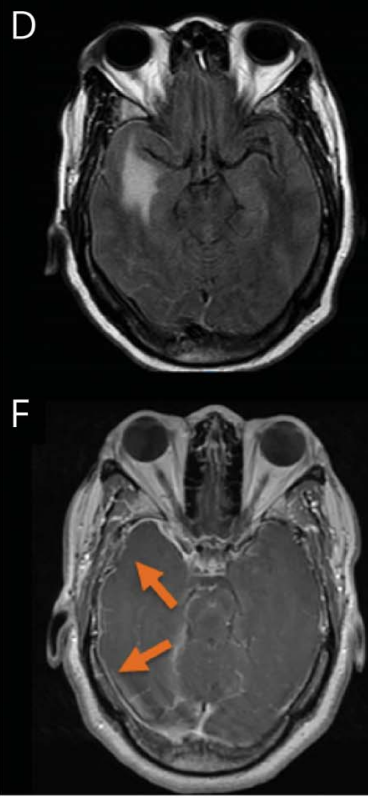

B

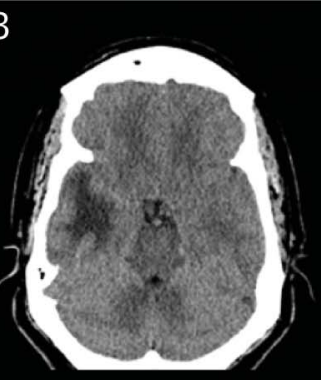

E

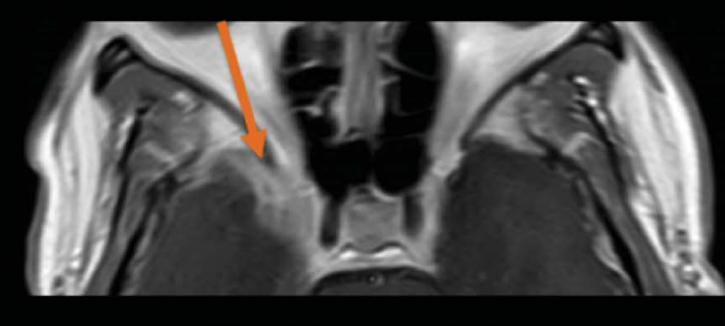

C

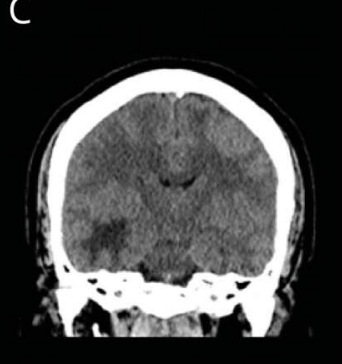

G

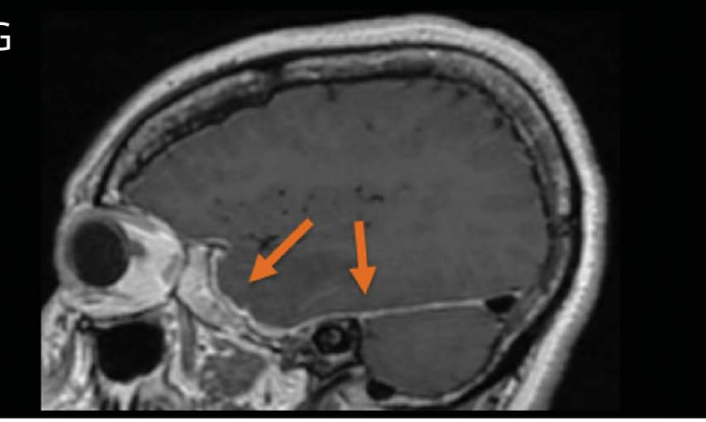

(A-C) CT head shows hypodensity in the right temporal lobe. (D) MRI brain did not reveal any abnormalities on T1 imaging. T2 sequence showed a hyperintense lesion in the temporal lobe. Post gadolinium images revealed meningeal enhancement in close proximity to the right optic nerve $(E$, arrow) and diffuse pachymeningeal enhancement around the right temporal lobe ( $\mathrm{F}$ and $\mathrm{G}$, arrows). No diffusion restriction was seen in the temporal lobe mass. eye visual blurring or history of forehead dysesthesia. A dedicated MRI of the orbits or skull base was not done as the patient's trigeminal symptoms had fully resolved prior to presentation, and her visual symptoms resolved after 2 days of admission. Given the diffuse meningeal involvement, it is possible that the optic or ophthalmic nerves had subtle areas of involvement that were not detected on a routine brain MRI. Furthermore, the ophthalmic nerve could have been affected in the cavernous sinus, where enhancement was seen.

Routine bloodwork and chemistry, erythrocyte sedimentation rate (ESR), and C-reactive protein were within normal limits. Serum protein electrophoresis, IgM, IgA, and IgG levels, including IgG4 levels, were normal. Additional inflammatory workup including serum antinuclear antibodies, antineutrophil cytoplasmic antibody, rheumatoid factor, and angiotensin-converting enzyme were negative. Serum hepatitis $C$ virus and HIV were negative. Hepatitis B antibody was positive, but core antigen was negative, consistent with the patient's prior hepatitis B infection.

Further workup included a lumbar puncture. CSF analysis showed slightly elevated protein $(0.89 \mathrm{mg} / \mathrm{dL})$, mild lymphocytic pleocytosis (29 leukocytes/mm3, 90\% lymphocytes), and normal glucose. Neuroinfectious workup included cryptococcal antigen, varicella-zoster virus, herpes simplex virus PCR, and acid-fast bacilli, and was negative. CSF cytology showed numerous relatively small lymphocytes without evidence for lymphoma. A CT chest, abdomen, and pelvis did not reveal any lesions amenable to biopsy and no lung changes to suggest prior or current tuberculosis infection.

Given the essentially unremarkable workup of the lesion, a brain biopsy was pursued. The biopsy of the skull base, meninges, and brain parenchyma showed histiocyte, lymphocyte, and plasma cell infiltrate with occasional lymphocytes embedded in the cytoplasm of macrophages, a phenomenon termed emperipolesis (figure 2). The majority of the cells expressed CD163, confirming histiocyte predominance. These cells also expressed CD68 and S100, and but not CD1a or langerin. There were no IgG4-positive plasma cells. A diagnosis of RDD was made and the patient was referred to the oncology clinic for further management.

\section{Discussion}

RDD is a rare histiocytosis first described in 1969,1 characterized by infiltration of activated histiocytes into affected 
Figure 2 Brain Biopsy

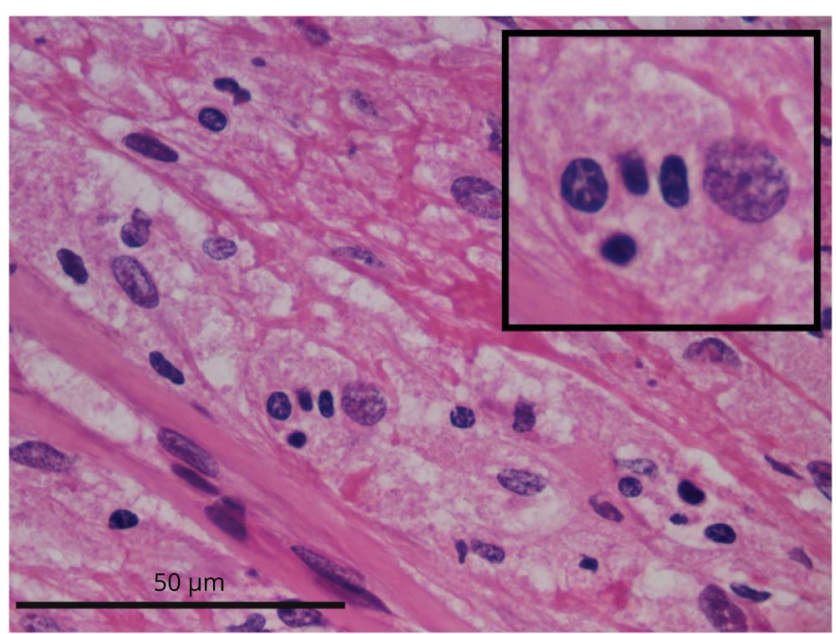

Occasional lymphocytes embedded in the cytoplasm of macrophages, a phenomenon called emperipolesis, best seen magnified in the inset (hematoxylin \& eosin stain).

organs. ${ }^{2} \mathrm{RDD}$ has a diverse range of clinical presentations, making diagnosis and management challenging. The differential diagnosis of RDD is broad and can include tuberculosis, granulomatous polyangiitis, sarcoidosis, IgG4-related disease (IgG4-RD), juvenile xanthogranuloma, other types of histiocytosis (such as Erdheim-Chester disease or Langerhans cell histiocytosis $[\mathrm{LCH}]$ ), and malignancies including lymphoma, plasma cell granuloma, leukemia, and melanoma. ${ }^{3-5}$ Diagnosing RDD is often further complicated by absent or nonspecific laboratory changes, including subtle elevation of ESR, hypergammaglobulinemia, or mild to moderate anemia. ${ }^{6}$

RDD typically presents with painless lymphadenopathy, often in the cervical chain. This can be associated with fever, weight loss, fatigue, and night sweats. Extranodal disease affecting a variety of organ systems is found in about $40 \%$ of people with $\mathrm{RDD}^{2,7}$; the nervous system is affected in only about $5 \%$ of cases. ${ }^{6}$ In those latter cases, isolated CNS disease appears to be far more common than secondary spread to the CNS, which may pose a diagnostic challenge to the neurologist. ${ }^{7}$ The symptoms of RDD affecting the CNS are often nonspecific and can include headache and seizures from mass effect or, as in our case, cranial nerve involvement. ${ }^{3}$ Patients with pituitary involvement can present with endocrine dysfunction. ${ }^{3,8}$ Disease of the spinal cord has been described, which may result in weakness, gait difficulty, and sensory abnormalities. ${ }^{2,6}$ Modern imaging technologies can help limit the differential diagnosis and provide useful information regarding the extent of the disease. On CT head imaging, RDD lesions typically present as single wellcircumscribed, extra-axial dural-based masses that are isodense or hyperdense. On MRI, the lesions are typically uniformly enhancing and isointense to brain parenchyma on
$\mathrm{T} 1$ and $\mathrm{T} 2$, with some hypointensity seen on $\mathrm{T} 2{ }^{4}$ This can be accompanied by vasogenic edema surrounding the lesion. Rarely, RDD lesions can present as parenchymal lesions that can spread to the dura and surrounding bone. ${ }^{8} \mathrm{RDD}$ is easily confused for meningioma because lesions are typically duralbased, uniformly enhanced, and can have a dural tail on imaging. ${ }^{9}$ In such cases, digital subtraction angiography may help distinguish between meningioma and RDD, based on the absence of arterial-venous shunting and hypervascularity expected with meningioma. ${ }^{10}$

A definitive diagnosis of RDD relies on biopsy. Histologically RDD histiocytes are positive for CD163, CD68, and S100 antigens, which are found on macrophages and dendritic cells. RDD is CD1a and langerin negative, which distinguishes it from $\mathrm{LCH}$. Like $\mathrm{LCH}, \mathrm{RDD}$ is a clonal proliferative disease, characterized by the overrepresentation of blood cells derived from a single clone. Characteristically RDD presents with emperipolesis, where intact lymphocytes or erythrocytes are found within histiocyte cytoplasm. ${ }^{6}$ RDD commonly contains abundant IgG4-positive plasma cells, ${ }^{11}$ and differential diagnosis with IgG4-RD may be difficult. In a small series of RDD cases, the amounts of IgG4-positive cells were found to be similar to those seen in IgG4-RD, suggesting overlap of RDD and IgG4-RD in some cases. ${ }^{10} \mathrm{RDD}$ can co-occur with other immunologic diseases in about $10 \%$ of cases, including systemic lupus erythematous, arthritis, or autoimmune hemolytic anemia.,

Treatment of RDD does not appear to be necessary in many cases. ${ }^{6}$ However, treatment modalities including surgery, chemotherapy, immunotherapy, and radiation have been used, especially when RDD results in functional impairment. For RDD of the nervous system, an algorithm including resection of lesions causing neurologic dysfunction and systemic therapy for unresectable or multifocal disease has been proposed. ${ }^{2}$ Our case of biopsy-proven $\mathrm{RDD}$ illustrates several learning points. Subtle cranial nerve symptoms or signs may point to a disease process that affects the skull base. Perineural spread into the right foramen ovale where the mandibular branch of the trigeminal nerve exits the skull and enhancement close to the intracranial part of the right optic nerve suggest that the transient sensory changes and blurred vision were caused by RDD. In the absence of evidence for systemic disease, we suggested a brain biopsy, which showed the pathognomonic findings of RDD. We did not identify additional immunologic abnormalities and the patient has since been comanaged with oncologists.

\section{Study Funding}

No targeted funding reported.

\section{Disclosure}

The authors report no disclosures relevant to the manuscript. Go to Neurology.org/N for full disclosures. 
Appendix Authors

\begin{tabular}{|c|c|c|}
\hline Name & Location & Contribution \\
\hline $\begin{array}{l}\text { Kia Gilani, } \\
\text { MD }\end{array}$ & $\begin{array}{l}\text { Department of } \\
\text { Medicine, Division of } \\
\text { Neurology, } \\
\text { University of } \\
\text { Toronto, Canada }\end{array}$ & $\begin{array}{l}\text { Drafting/revision of the } \\
\text { manuscript for content, including } \\
\text { medical writing for content; major } \\
\text { role in the acquisition of data; } \\
\text { analysis or interpretation of data }\end{array}$ \\
\hline $\begin{array}{l}\text { Stephanie } \\
\text { Kuntz, MD }\end{array}$ & $\begin{array}{l}\text { Department of } \\
\text { Medicine, Division of } \\
\text { Neurology, } \\
\text { University of } \\
\text { Toronto, Canada }\end{array}$ & $\begin{array}{l}\text { Drafting/revision of the } \\
\text { manuscript for content, including } \\
\text { medical writing for content; major } \\
\text { role in the acquisition of data; } \\
\text { analysis or interpretation of data }\end{array}$ \\
\hline $\begin{array}{l}\text { David G. } \\
\text { Munoz, } \\
\text { MD, } \\
\text { FRCP(C) }\end{array}$ & $\begin{array}{l}\text { Department of } \\
\text { Laboratory Medicine } \\
\text { \& Pathobiology, } \\
\text { University of } \\
\text { Toronto, Canada }\end{array}$ & $\begin{array}{l}\text { Drafting/revision of the } \\
\text { manuscript for content, including } \\
\text { medical writing for content; } \\
\text { analysis or interpretation of data }\end{array}$ \\
\hline $\begin{array}{l}\text { Raphael } \\
\text { Schneider, } \\
\text { MD, PhD, } \\
\text { FRCP(C) }\end{array}$ & $\begin{array}{l}\text { Department of } \\
\text { Medicine, Division of } \\
\text { Neurology, } \\
\text { University of } \\
\text { Toronto, Canada }\end{array}$ & $\begin{array}{l}\text { Drafting/revision of the } \\
\text { manuscript for content, including } \\
\text { medical writing for content; major } \\
\text { role in the acquisition of data; } \\
\text { study concept or design; analysis } \\
\text { or interpretation of data }\end{array}$ \\
\hline
\end{tabular}

\section{References}

1. Rosai J, Dorfman RF. Sinus histiocytosis with massive lymphadenopathy: a newly recognized benign clinicopathological entity. Arch Pathol. 1969;87:63-70.

2. Abla O, Jacobsen E, Picarsic J, et al. Consensus recommendations for the diagnosis and clinical management of Rosai-Dorfman-Destombes disease. Blood. 2018;131: 2877-2890.

3. Adeleye AO, Amir G, Fraifeld S, Shoshan Y, Umansky F, Spektor S. Diagnosis and management of Rosai-Dorfman disease involving the central nervous system. Neurol Res. 2010;32:572-578.

4. Zhu H, Qiu L-H, Dou Y-F, et al. Imaging characteristics of Rosai-Dorfman disease in the central nervous system. Eur J Radiol. 2012;81:1265-1272.

5. Dalia S, Sagatys E, Sokol L, Kubal T. Rosai-Dorfman disease: tumor biology, clinical features, pathology, and treatment. Cancer Control. 2014;21:322-327.

6. Cooper SL, Jenrette JM. Rosai-Dorfman disease: management of CNS and systemic involvement. Clin Adv Hematol Oncol. 2012;10:199-202.

7. Foucar E, Rosai J, Dorfman R. Sinus histiocytosis with massive lymphadenopathy (Rosai-Dorfman disease): review of the entity. Semin Diagn Pathol. 1990;7: 19-73.

8. Sandoval-Sus JD, Sandoval-Leon AC, Chapman JR, et al. Rosai-Dorfman disease of the central nervous system: report of 6 cases and review of the literature. Medicine. 2014;93:165-175.

9. Alimli AG, Oztunali C, Boyunaga OL, Pamukcuoglu S, Okur A, Borcek AO. MRI and CT findings of isolated intracranial Rosai-Dorfman disease in a child. Neuroradiol J. 2016;29:146-149.

10. Wang Y, Camelo-Piragua S, Abdullah A, Ibrahim M, Parmar HA. Neuroimaging features of CNS histiocytosis syndromes. Clin Imag. 2020;60:131-140.

11. Menon MP, Evbuomwan MO, Rosai J, Jaffe ES, Pittaluga S. A subset of RosaiDorfman disease cases show increased IgG4-positive plasma cells: another red herring or a true association with IgG4-related disease? Histopathology. 2013;64: 455-459.

\section{COVID-19 and Neurologic Disease: Call for Papers!}

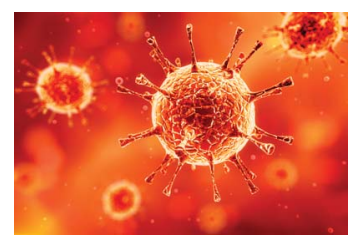

The editors of Neurology are interested in papers that address the neurological aspects of COVID-19 infection and challenges to the management of patients with chronic neurological conditions who have, or are at risk for, the infection. Relevant papers that pass initial internal review will undergo expedited peer review and online publication. We will consider papers posted in preprint servers.

Submit observational studies and clinical trials as Articles and case series and case reports under the Clinical/Scientific Notes category to https://submit.neurology.org/ today!

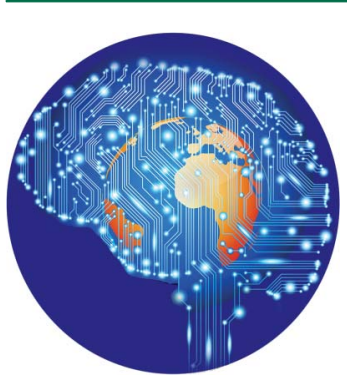

\section{Practice Current: An interactive exchange on controversial topics}

Share your own best practices.

Read commentary with expert opinion.

Explore results on an interactive world map.

NPub.org/NCP/practicecurrent

Neurology ${ }^{\circledR}$ Clinical Practice 


\section{Neurology}

\section{Pearls \& Oy-sters: Rosai-Dorfman Disease of the CNS \\ Kia Gilani, Stephanie Kuntz, David G. Munoz, et al.}

Neurology 2021;96;1055-1058 Published Online before print April 13, 2021

DOI 10.1212/WNL.0000000000012035

This information is current as of April 13, 2021

$\begin{array}{ll}\begin{array}{l}\text { Updated Information \& } \\ \text { Services }\end{array} & \begin{array}{l}\text { including high resolution figures, can be found at: } \\ \text { http://n.neurology.org/content/96/22/1055.full }\end{array} \\ \text { References } & \text { This article cites } 11 \text { articles, } 1 \text { of which you can access for free at: } \\ & \text { http://n.neurology.org/content/96/22/1055.full\#ref-list-1 } \\ \text { Subspecialty Collections } & \text { This article, along with others on similar topics, appears in the } \\ & \text { following collection(s): } \\ & \text { All Immunology } \\ \text { http://n.neurology.org/cgi/collection/all_immunology } & \text { All Oncology } \\ \text { http://n.neurology.org/cgi/collection/all_oncology } \\ \text { Autoimmune diseases } \\ \text { http://n.neurology.org/cgi/collection/autoimmune_diseases } \\ \\ \text { Information about reproducing this article in parts (figures,tables) or in } \\ \text { its entirety can be found online at: } \\ \text { http://www.neurology.org/about/about_the_journal\#permissions } \\ \text { Pnformation about ordering reprints can be found online: } \\ \text { http://n.neurology.org/subscribers/advertise }\end{array}$

Neurology ${ }^{\circledR}$ is the official journal of the American Academy of Neurology. Published continuously since 1951, it is now a weekly with 48 issues per year. Copyright @ 2021 American Academy of Neurology. All rights reserved. Print ISSN: 0028-3878. Online ISSN: 1526-632X.

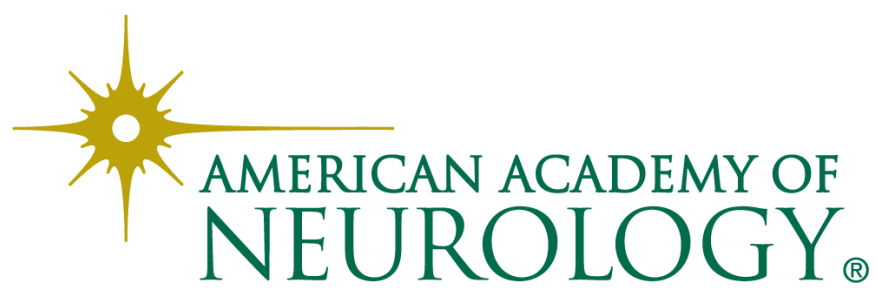

